Journal of Social and Development Sciences

Vol. 4, No. 7, pp. 303-307, July 2013 (ISSN 2221-1152)

\title{
The New Takeover Code by the Securities and Exchange Board of India
}

\author{
*Varsha Das, Aishwarya Mishra \\ Kiit School of Law, Kiit University, Odisha, India \\ *dasvarsha_24@yahoo.com
}

\begin{abstract}
Merger \& Acquisition in India have been governed by the age-old takeover rules. It seems that now, the Securities and Exchange Board of India (SEBI) has realized that these rules need to be revamped to keep them in line with the ever-changing global scenario. On September 2011, the SEBI amended the new set of takeover rules i.e.; the SEBI (Substantial Acquisition of Shares and Takeovers) Regulations, 2011. The main purpose is to prevent hostile takeovers and at the same time, provide some more opportunities of exit to innocent shareholders who do not wish to be associated with a particular acquirer. With these rules coming into force, both promoter and public shareholders of a listed company would now get the same price for their shares being purchased by an acquirer. In another shareholder-friendly move, SEBI has scrapped the noncompete fee or control premium, which were being paid to only the promoters earlier and could have been as much as $25 \%$ of the public offer price. The SEBI has successfully done one part of the reform process by preparing the new takeover code, the other part requires it successful implementation.
\end{abstract}

Keywords: Takeover, Code, Shareholders, Promoter, SEBI, Rules, Offer Price, Premium, Listed

\section{Introduction}

For the past few years, the M\&A deals in India have been governed by the age-old takeover rules. A lot has changed in the corporate world during this while. It seems that now, the SEBI has realized that these rules need to be revamped to keep them in line with the ever-changing global scenario. Hence, earlier this year, the SEBI has notified the new takeover rules. The law prescribing the rules of takeover of listed companies in India is more than 9 years old. It was formulated by the Securities and Exchange Board of India (SEBI) and is called the SEBI (Substantial Acquisition of Shares and Takeovers) Regulations, 1997 (Takeover Code or Takeover Regulations). During these 9 years, the Takeover Code has been amended about 5 times with the latest amendment made on May 26, 2006. The latest amendment has not brought any major changes in the Regulations, except that the definition of promoter has been revamped. Further, the modifications have expanded the scope and application of the Takeover Code.

The article highlights the new Takeover Code, 2011 that adheres to the framework and principles of the Takeover Code, 1997 but the changes that it brings about are significant. This article provides an overview of the Takeover Code, 2011 and discusses some of the most important amendments that have been brought about.

\section{Methodology}

This is to specify that the research methodology adopted throughout the project is doctrinal. Materials have been referred to in general sense. The experience and observations in this aspect are an integral part of this project. The methodology of research has been both descriptive and analytical. The researcher has used majorly secondary source of data. As part of the secondary research, the data has been collected from books, articles, websites, etc.

The Highlights of the New Takeover Code 2011: The M\&A landscape in India is all set to change, and this time for the right cause. On 23rd September, 2011, the Securities and Exchange Board of India (SEBI) amended the age old takeover rules and notified them with the new set of takeover rules i.e.; the SEBI (Substantial Acquisition of Shares and Takeovers) Regulations, 2011 (commonly referred to as the takeover 
code) to align it closer to global practices. While the new takeover code is being appreciated by many industry experts, one can still hear some voices not completely in appreciation of the new takeover code. The main purpose for the new takeover code is also to prevent hostile takeovers and at the same time, provide some more opportunities of exit to innocent shareholders who do not wish to be associated with a particular acquirer.

\section{Limits on acquisition of shares or voting rights}

Initial threshold limit: Increase in threshold limit, from $15 \%$ to $25 \%$, provides more headroom for acquisition. No transition provision for acquirers holding $15 \%$ or more but less than $25 \%$ voting rights in the target company. Any person, singly or together with PACs (together referred to as acquirer), can acquire up to $24.99 \%$ shares or voting rights in a listed company in India (target company), provided the acquirer does not take control over the target company. If the acquisition results into entitlement of $25 \%$ or more voting rights in the target company, the acquirer is required to make an open offer to acquire at least $26 \%$ shares from the existing public shareholders of the target company in terms of the Takeover Code (open offer obligation).

Creeping acquisition limit: Creeping acquisition of 5\%, in a financial year, is allowed up to the maximum permissible non-public shareholding (generally $75 \%$ ). The acquirer holding $25 \%$ or more voting rights in the target company can acquire additional shares or voting rights to the extent of $5 \%$ of the total voting rights in any financial year, up to the maximum permissible non-public shareholding limit (generally $75 \%$ ). Acquisition of voting rights exceeding $5 \%$ in any financial year triggers open offer obligation. For computing, the said 5\%creeping acquisition limit:

- Gross acquisitions will be considered without netting off any reduction in shareholding or voting rights owing to disposal of shares or dilution of voting rights on new issue of shares by the target company.

- In case of a new issue of shares by the target company to the acquirer, the difference between the pre and post allotment percentage of voting rights will be regarded as the quantum of additional acquisition.

Acquisition of 'control': A director or officer of the target company is not considered in control over it merely by virtue of such a position. Exemption from open offer obligation because of change in control from joint control to sole control is not covered, unlike the 1997 Code, in the Takeover Code.

Acquisition of control: Acquisition of control, directly or indirectly, by the acquirer, irrespective of shares or voting rights held, triggers open offer obligation. Indirect acquisition of control is categorized into three types, based on the value* of the target company relative to overall transaction. Each such type of indirect acquisition is subject to distinct norms as to offer price computation, disclosures, offer timing, etc. The Takeover Code does not exempt change in control, pursuant to special resolution of shareholders of the target company, from open offer obligation (whitewash provision - which was available under the 1997 Code).

\section{Open offer: Trigger and conditions}

Mandatory open offer: A mandatory open offer gets triggered on any of the following cases:

- Acquisition of substantial shares or voting rights entitling the acquirer to $25 \%$ or more voting rights in the target company.

- Creeping acquisition of more than $5 \%$ voting rights in a financial year by the acquirer who already holds $25 \%$ or more voting rights in the target company.

- Acquisition of control over the target company, irrespective of shares or voting rights held by the acquirer.

In a mandatory open offer, the acquirer has to offer to acquire minimum $26 \%$ of the total shares of the target company from public shareholders, in accordance with the Takeover Code. 
Voluntary open offer: The acquirer holding $25 \%$ or more voting rights in the target company can make a voluntary offer for at least $10 \%$ of the total shares of the target company. This is subject to fulfillment of the following conditions:

- Total shareholding of the acquirer post open offer should not exceed maximum permissible nonpublic shareholding (generally $75 \%$ ).

- The acquirer should not have acquired shares of the target company in the preceding 52 weeks without attracting open offer obligation.

- Conditions are prescribed for voluntary open offers.

- Minimum offer size is reduced from $20 \%$ to $10 \%$ to promote consolidation of holdings in a fair and transparent manner.

\section{Key aspects of open offer obligations}

Offer size: The minimum offer size of $26 \%$ of the total shares of the target company needs to be computed, as of $10^{\text {th }}$ working day from the closure of the tendering period. The total shares as of the 10th working day should take into account all potential increases in the number of outstanding shares during the offer period contemplated as of the date of PA. In case of an increase in the total number of shares post PA, not contemplated as on the date of PA, the offer size will need to be increased proportionately. If open price is incapable of being determined for indirect acquisition, it will be determined by the acquirer and manager to offer by taking valuation parameters into account. In case of indirect acquisition, the offer price will be enhanced at the rate of $10 \%$ per annum for the period between:

- The date on which the primary acquisition is contracted or the date of announcing the intention or decision of making the primary acquisition, whichever is earlier.

- The date on which the PA is made to the shareholders of the target company

- Valuation of the target company to be carried out and disclosed in case of indirect acquisition of the target company, if its value exceeds $15 \%$ of overall transaction. Non-compete fees must form part of negotiated price and will be used as a benchmark to determine the offer price

Mode of payment: Offer price may be paid through any one or a combination of any of the following:

- Cash

- Issue, exchange or transfer of:

1. Listed equity shares of the acquirer or PACs

2. Listed debt instruments issued by the acquirer or PACs (with rating not inferior to investment grade).

3. Convertible debt securities entitling the holder to acquire listed shares* of the acquirer or PACs

Conditional offer: An acquirer may make an open offer conditional as to minimum level of acceptance (conditional offer). If the offer is pursuant to an agreement, such agreement must contain a clause to the effect that in case minimum level of acceptance is not achieved, the acquirer will not acquire any shares under the open offer. In case of a conditional offer, the acquirer will not acquire any share in the target company during the offer period.

\section{Competing offer}

- Competing offer can be made within 15 working days from the date of DPS made by the acquirer who makes the first PA.

- Unless the first open offer is a conditional offer, the competing offer cannot be made conditional as to the minimum level of acceptance.

- A competing offer is not regarded as a voluntary open offer and therefore all the provisions of the Takeover Code, including that of offer size, apply accordingly.

- On PA of competing offer, an acquirer who has made a preceding offer is allowed to revise the terms of his open offer; if the terms are more beneficial to the shareholders of the target company. The upward revision of the offer price can be made any time up to three working days prior to commencement of the tendering period. 
Withdrawal of offer: An open offer once made can be withdrawn under any of the following circumstances:

- Statutory approvals for open offer or for effecting acquisitions attracting the obligation to make an open offer are refused, if the requirement for approval is disclosed in the DPS and LO.

- The acquirer, being a natural person, dies.

- Any condition stipulated in the agreement for acquisition attracting the obligation to make an open offer is not met for reasons beyond control of the acquirer, if the conditions have been disclosed in the DPS and LO.

- Such other circumstances as in the opinion of SEBI, merits withdrawal.

Minimum public shareholding: Acquirer cannot delist voluntarily for a year from open offer, if his shareholding exceeds maximum permissible limit. The acquirer is not entitled to acquire or enter into any agreement to acquire shares or voting rights exceeding maximum permissible non-public shareholding (generally $75 \%$ ).

- If maximum permissible non-public shareholding exceeds, say $75 \%$, pursuant to open offer - the acquirer is required to bring down his or her shareholding to $75 \%$ within the time specified as per SCRR.

- The acquirer, whose shareholding exceeds $75 \%$ pursuant to an open offer, cannot make a voluntary

- Delisting offer under the SEBI. Delisting Regulations, for one year from the date of completion of open offer.

\section{Disclosures}

Disclosure of Acquisition or Disposal: An Acquirer making an Acquisition under the Takeover Code, 2011 in a Target Company where the acquired shares and voting rights together with any existing shares or voting rights of the Acquirer and PAC amount to $5 \%$ or more of the shareholding of the Target Company, shall make disclosures of their aggregate shareholding and voting rights in such Target Company and every Acquisition or disposal of shares of such Target Company representing $2 \%$ or more of the shares or voting rights in such Target Company. The disclosure required under the Takeover Code, 2011 shall be made within 2 working days of the receipt of intimation of allotment of shares, or the Acquisition of shares or voting rights in the Target Company to:

- $\quad$ Every stock exchange where the shares of the Target Company are listed; and

- The Target Company at its registered office.

The Takeover Code, 2011 provides for more frequent and stringent disclosures on the part of the Acquirer. There has been a significant amendment in the previous Regulation 7 of the Takeover Code, 1997 that dealt with the Acquisition of 5\% and more shares or voting rights of a company. Erstwhile Regulation 7 stipulated that disclosures of shareholding have to be made on the Acquisition of more than $5 \% 10 \%, 14 \%, 54 \%$ and $74 \%$ shares in the Target Company. The Takeover Code, 2011 removes the disclosure in 5 stages. Regulation 28 of the Takeover Code, 2011 states that a disclosure will be made at the time of the Acquisition of $5 \%$ of the shares or voting rights in the company.

Responsibility of directors and independent directors of the target company: There is a significant change in the general obligations of the Board of Directors of a Target Company under the Takeover Code, 1997 and the Takeover Code, 2011. The Takeover Code, 1997 had given a discretionary option to the board of directors to send their recommendations on the open offer to the shareholders and for the purpose, the Board could seek the opinion of an independent merchant banker or a committee of independent directors. The Takeover Code, 2011, however, makes it mandatory for the board of directors of the Target Company to constitute a committee of independent directors (who are entitled to seek external professional advice on the same) to provide written reasoned recommendations on such open offer, which the Target Company is required to publish. 
Repeal and Savings: Acts completed or PA already made under the 1997 Code is not impacted. The 1997 Code stands repealed from the date the new Takeover Code comes into force, i.e. 22 October 2011. Once the 1997 Code gets repealed, any reference made thereof in any other regulations, guidelines or circulars issued by SEBI shall be considered to be a reference to the provisions of the new Takeover Code. Notwithstanding such repeal, an offer for which PA was made under the 1997 Code will be required to continue and completed as per the 1997 Code itself.

\section{Conclusion}

The Takeover Code has weathered the test of time in the unique and peculiar Indian business environment where convoluted cross-holdings and dummy shareholders have been a norm. With every amendment, SEBI has endeavored to make the Code more efficient and effective. This amendment has also been made with the purpose of streamlining and balancing the code and making it wider in its application. SEBI has been in itself one of the best regulators of securities market in the world. Its efforts in making the securities market more advanced, sophisticated yet fair and clean are commendable. Though the new takeover code has increased the threshold limit and the minimum offer size, it is also felt that the RBI should do away with the restriction on banks to fund domestic acquisitions. The SEB has successfully done one part of the reform process by preparing the new takeover code; the other part requires it successful implementation. Let us hope that it is able to do so.

\section{Reference}

Srinivasan, A. G. (2011). Law Relating to New Takeover Code 2011, CA SRINIVASAN ANAND G -Division One, Taxmann.

(2011). SEBI makes it mandatory for companies to disclose promoters' shares. Economic Times. Oct 6, Retrieved 26 October 2012.

Vijay, K. P. (2011). New Takeover Code - A Mirror of the Dynamic Economy", ASSOCHAM jointly with Corporate Knowledge Foundation, 40-105. 